\title{
Abundance of autotrophic, mixotrophic and heterotrophic planktonic ciliates in shelf and slope waters
}

\author{
Diane K. Stoecker, Akira Taniguchi*, Ann E. Michaels \\ Biology Department, Woods Hole Oceanographic Institution, Woods Hole, Massachusetts 02543, USA
}

\begin{abstract}
During early summer, the density of microplanktonic ciliates in the euphotic zone on Georges Bank (Northwest Atlantic) ranged from 600 to 13000 cells $1^{-1}$; in the slope waters to the southeast of the bank, densities ranged from 1900 to 2800 cells $1^{-1}$. Myrionecta rubra, a photosynthetic autotroph ciliate with a reduced algal endosymbiont, numerically comprised an average of $30 \%$ of the microplanktonic ciliate fauna at stations in $<100 \mathrm{~m}$ depth, but $3 \%$ or less of the ciliate fauna at the deeper stations. Oligotrichous ciliates with chloroplasts are estimated to have contributed $34 \%$ of the ciliate fauna and were abundant at both shallow, unstratified stations on the bank and at deeper, stratified stations on the slope of the continental shelf and in the Gulf of Maine. Overall, about $50 \%$ of the ciliates in the euphotic zone contained chlorophyll. At the shallow water stations, 2 species, $M$. rubra and Laboea strobila (a mixotrophic oligotrich) accounted for over 50\% of the biomass of ciliates with chlorophyll. At an irradiance of $100 \mu \mathrm{E} \mathrm{m}^{-2} \mathrm{~s}^{-1}$, M. rubra and L. strobila had photosynthetic rates of 85 and $465 \mathrm{pg} \mathrm{C}$ fixed cell $\mathrm{C}^{-1} \mathrm{~h}^{-1}$, respectively. During summer, when phytoplankton biomass is low, autotrophic and mixotrophic ciliates may make an important contribution to photosynthesis in the larger size fractions and be an important source of food for larger organisms that rely on high quality, $\geq 15$ to $20 \mu \mathrm{m}$ food particles.
\end{abstract}

\section{INTRODUCTION}

Many marine planktonic ciliates contain chlorophyll and are photosynthetic. We operationally define chlorophyll-containing ciliates as specimens with overall red or orange epifluorescence due to the presence of relatively large amounts of undergraded plant pigment. The pigments may be in isolated plastids or in algal endosymbionts within the ciliates' cytoplasm (Laval-Peuto \& Rassoulzadegan 1988). These chlorophyll-containing taxa include Myrionecta rubra (= Mesodinium rubrum) and some ciliates in the family Strombidiidae, order Oligotrichida (Kahl 1932, Blackbourn et al. 1973, McManus \& Fuhrman 1986, LavalPeuto et al. 1986, Jonsson 1987 a, Stoecker \& Silver 1987, Stoecker et al. 1987a, Laval-Peuto \& Rassoulzadegan 1988). Myrionecta rubra is thought to be an

\footnotetext{
- Present address: Laboratory of Oceanography, Faculty of Agriculture, Tohoku University, Sendai 980, Japan
}

obligate photoautotroph and has a highly modified algal endosymbiont (reviewed in Lindholm 1985). It occasionally produces non-toxic 'red tides' in neritic and upwelling areas, but it occurs more regularly at lower densities which do not form visible patches (Gieskes \& Kraay 1983, McManus \& Fuhrman 1986, Dale 1987). Marine oligotrichous ciliates with chlorophyll are usually mixotrophic, deriving their energy from 2 sources (Sieburth \& Estep 1985): photosynthesis and phagocytosis (Blackbourn et al. 1973, Laval-Peuto et al. 1986, Jonsson 1987a, Stoecker \& Silver 1987, Stoecker et al. 1988). In neritic waters, about $40 \%$ of the microplanktonic ciliate fauna has been reported to contain chloroplasts (Stoecker et al. 1987a). Occasionally, oligotrichs with chloroplasts reach bloom densities (Dale \& Dahl 1987, Reid 1987).

Shelf-slope ecosystems occupy a relatively small portion of the world's ocean but yield over $99 \%$ of the global fish catch (Walsh 1981). Among the most productive of these shelf/slope ecosystems is Georges Bank in the Northwest Atlantic (Cohen \& Grosslein 
1987, O'Reilly et al. 1987). Although ciliates are thought to be important trophic links in planktonic food webs (Beers \& Stewart 1969, Pomeroy 1974, Porter et al. 1979, Conover 1982, Sherr et al. 1986) little quantitative information is available on the distribution of ciliates on Georges Bank (Bigelow et al. 1940). There were no quantitative data on the over-all abundance of chlorophyll-containig ciliates in continental shelf/slope ecosystems.

During July, 1987 we investigated the distribution of ciliates, with and without chlorophyll, across Georges Bank (Fig. 1). Fairly sharp bathymetric changes occur over this part of the continental shelf. During summer, well-mixed bank waters lie adjacent to stratified waters in the Gulf of Maine and over the slope to the south (reviewed in Cura 1987, O'Reilly et al. 1987). Interactions between relatively warm, salty slope water and cold, less salty Scotian Shelf water causes strong seasonal fronts to form around the Bank. The ciliate fauna was sampled and compared across these strong physical, chemical, and biological gradients.

In conjunction with our survey, we made measurements of photosynthetic ${ }^{14} \mathrm{C}$ uptake by the phytoplankton community as a whole and by 2 abundant ciliates, Myrionecta rubra and Laboea strobila. These data are useful in making preliminary estimates of the potential contribution of ciliates to photosynthesis in shelf waters.

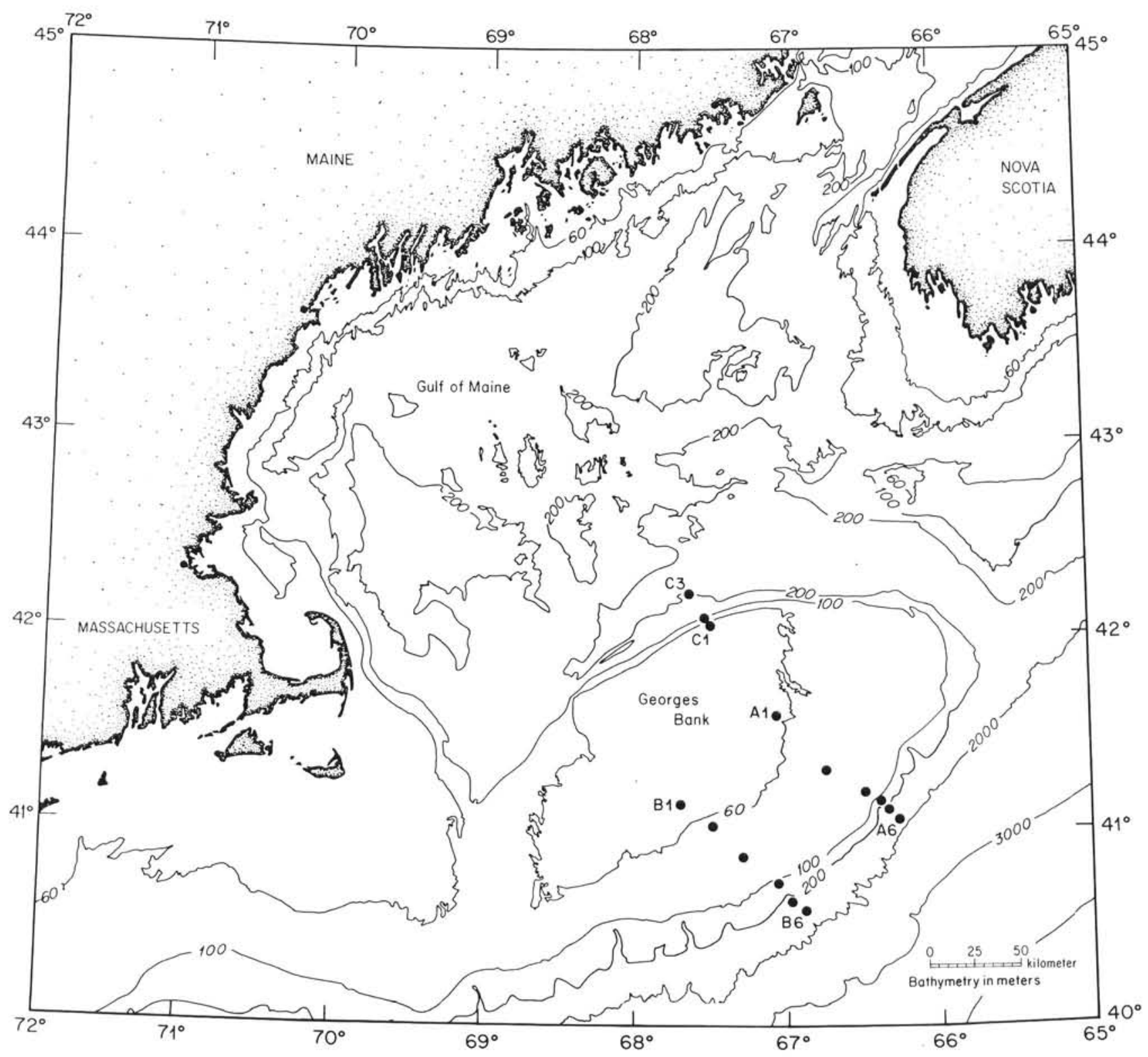

Fig. 1. Station locations, 'Oceanus' Cruise 190, 1 to 8 July 1987 


\section{METHODS}

Between 1 and 8 July 1987, 15 stations were sampled on and around Georges Bank (Fig. 1). Two transects (A \& B) crossed the southern flank from the shallow bank waters to the edge of the continental slope. Three stations were sampled on Transect $C$, at the northern edge of Georges Bank. The most northern station, C3, was in the Gulf of Maine.

Sampling along the transects was done during daylight. At each station, irradiance was measured with a Li-Cor Quantum Photometer (model Li-185 B equipped with a spherical sensor) to the depth of the $1 \%$ light level. Temperature and salinity profiles were obtained with a Seacat Profiler (Seabird Electronics). Water samples were collected from the surface to below the depth of the $1 \%$ light level at $10 \mathrm{~m}$ intervals with a string of 101 Niskin bottles. Duplicate samples from the bottles were analyzed for ammonia, nitrate, nitrite and chlorophyll (Parsons et al. 1984a).

To $25 \mathrm{ml}$ of $20 \%$ formaldehyde buffered with $100 \mathrm{~g}$ $1^{-1}$ of hexamethylenetetramine (Sigma Chemical Co.), $225 \mathrm{ml}$ water samples were added to produce a final concentration of $2 \%$ formaldehyde. The samples were stored at $4^{\circ} \mathrm{C}$ in the dark and examined within $5 \mathrm{wk}$ of collection. Previous studies with samples from Woods Hole have shown that 80 to $90 \%$ of the total ciliates are preserved with this technique (Stoecker unpubl.). Although other fixatives, such as acid Lugol's, may give higher counts (Gifford 1985), these methods do not permit the use of epifluorescence for the detection of plant pigments within cells.

One hundred $\mathrm{ml}$ subsamples were concentrated using settling chambers and examined with a Zeiss inverted microscope equipped for transmitted light and epifluorescence microscopy (BP 450 to $490 \mathrm{~nm}$ excitation filter, FT $510 \mathrm{~nm}$ chromatic beam splitter, LP $520 \mathrm{~nm}$ barrier filter, and a $50 \mathrm{~W}$ mercury burner). All ciliates 15 to $20 \mu \mathrm{m}$ or larger in size were counted; smaller ciliates, if present in our samples, may not have settled quantitatively. Bacterivorous ciliates $<15$ to $20 \mu \mathrm{m}$ in size often comprise a sizeable fraction of the ciliate biomass in nearshore, organic-rich environments (Sherr et al. 1986), but in the Gulf of Maine, Georges Bank, and in slope waters they represent a small percent of the planktonic ciliate biomass, except perhaps at the pycnocline were bacterial concentrations may be higher (Montagnes et al. 1988, Stoecker unpubl.). Epifluorescence microscopy was used to distinguish between ciliates with and without chlorophyll. With this technique, ciliates with chloroplasts are readily distinguishable from non-pigmented, strictly heterotrophic specimens although heterotrophic forms often contain some undegraded plant pigments in their digestive vacuoles (Stoecker et al. 1987a, Laval-Peuto \& Rassoulzadegan 1988). Heterotrophic ciliates were further categorized as tintinnids, oligotrichs or 'other'. Among the chlorophyll-containing ciliates, 2 types are easily identified to species, Myrionecta rubra (= Mesodinium rubrum) (Lindholm 1985, Small \& Lynn 1985) and Laboea strobila (Maeda \& Carey 1985, Montagnes et al. 1988). The other types of ciliates with chlorophyll were enumerated separately, but only identified to genus based on Small \& Lynn (1985) and Maeda \& Carey (1985).

Representative, fixed specimens of each type were measured with an ocular micrometer and geometric approximations were used to calculate average cell volumes. A carbon-to-volume relationship of $0.08 \mathrm{pg} \mathrm{C}$ $\left(\mu \mathrm{m}^{3}\right)^{-1}$ was used to estimate biomass; this is based on $\mathrm{CHN}$ determinations for 2 heterotrophic ciliates (Stoecker \& Evans 1985), corrected for volume changes caused by fixation (Choi unpubl.). We were interested in relations between the occurrence of photosynthetic ciliates and phytoplankton and therefore tested for correlations between chlorophyll concentration and the frequency or abundance of different types of ciliates with chlorophyll.

We performed a $24 \mathrm{~h}$ drogue study to determine whether the ciliates with chloroplasts stayed in the euphotic zone. A 'holey sock' drogue (diameter $0.6 \mathrm{~m}$, length $5 \mathrm{~m}$ ) (Geyer unpubl.) was set at $15 \mathrm{~m}$ depth at Station A1' and followed for $24 \mathrm{~h}$. Samples were taken in the vicinity of the drogue every $4 \mathrm{~h}$. Sampling procedures were similar to those described previously.

Photosynthesis studies were conducted at the 3 stations on the bank (A1, B1, C1) and at the station in the Gulf of Maine (C3) (Fig. 1). Between 08:00 and 09:00 h, water samples were collected from the surface with a plastic bucket. Volumes of $250 \mathrm{ml}$ were preserved with buffered formalin for later enumeration of the ciliates with chlorophyll. Triplicate samples were collected on GF/F filters for chlorophyll a determinations. The amount of chlorophyll in the microplankton size fraction ( $\geq 20 \mu \mathrm{m}$ ) was estimated by taking the difference between the total chlorophyll and the chlorophyll passing a $20 \mu \mathrm{m}$ Nitex mesh.

Single cell techniques modified from Rivkin \& Seliger (1981) were used to determine photosynthetic carbon uptake. GF/F filtered seawater was spiked to ca $0.5 \mu \mathrm{Ci} \mathrm{ml}{ }^{-1}$ with ${ }^{14} \mathrm{C}$ bicarbonate (specific activity, 53 $\mathrm{mCi} \mathrm{mmol}^{-1}$, New England Nuclear) and divided, $2 \mathrm{ml}$ vial $^{-1}$, among the scintillation vials used for the incubation. Triplicate $100 \mu \mathrm{l}$ samples of the spiked seawater were taken for determination of the actual total activity available for uptake. Under a dissecting scope equipped with dark field illumination, pigmented oligotrichs were removed with a Pasteur pipette from whole water samples, washed twice in GF/F filtered seawater, and then transferred to individual vials containing the spiked seawater. 
Table 1. Summary of station characteristics, Georges Bank, July 1987, 'Oceanus' Cruise 190

\begin{tabular}{|c|c|c|c|c|c|c|c|c|c|}
\hline \multirow[t]{2}{*}{ Station } & \multirow{2}{*}{$\begin{array}{l}\text { Approx. depth } \\
\text { (m) }\end{array}$} & \multirow{2}{*}{$\begin{array}{l}\text { Surface temp. } \\
\qquad\left({ }^{\circ} \mathrm{C}\right)\end{array}$} & \multirow{2}{*}{$\begin{array}{l}\text { Depth of } 1 \% \\
\text { light level } \\
\text { (m) }\end{array}$} & \multirow{2}{*}{$\begin{array}{l}\text { Depth of } \\
\text { thermocline }(\mathrm{m})\end{array}$} & \multirow{2}{*}{$\begin{array}{l}\text { Depth of Chl. } \\
\text { max. (m) }\end{array}$} & \multicolumn{4}{|c|}{ Means for depth above $1 \%$ light level } \\
\hline & & & & & & Chl. a $\left(\mu \mathrm{g} \mathrm{l}^{-1}\right)$ & $\begin{array}{l}\text { Ammonia } \\
(\mu M)\end{array}$ & $\begin{array}{c}\text { Nitrite } \\
(\mu M)\end{array}$ & $\begin{array}{c}\text { Nitrate } \\
(\mu M)\end{array}$ \\
\hline \multicolumn{10}{|c|}{ Southern Flank } \\
\hline A1 & 55 & 11.3 & 29 & none & none & 1.23 & 0.27 & 0.17 & 1.58 \\
\hline A2 & 73 & 11.8 & 29 & $10-20$ & 20 & 1.79 & 0.41 & 0.34 & 0.93 \\
\hline $\mathrm{A} 3$ & 92 & 12.5 & 31 & $17-25$ & 20 & 0.71 & 0.01 & ND & ND \\
\hline A4 & 183 & 12.6 & 38 & $10-20$ & 20 & 0.81 & 0.18 & 0.19 & $1.80^{\mathrm{a}}$ \\
\hline A5 & 915 & 14.1 & 46 & $17-24$ & $30-50$ & 0.95 & 0.11 & 0.15 & $1.15^{\mathrm{a}}$ \\
\hline A6 & 1830 & 18.1 & 48 & 45 & 40 & 0.38 & 0.10 & 0.02 & $0.72^{\mathrm{a}}$ \\
\hline B1 & 55 & 12.3 & 31 & none & $10-20$ & 0.75 & 0.06 & 0.00 & 0.05 \\
\hline B2 & 73 & 13.5 & 34 & $12-22$ & 20 & 0.97 & 0.24 & 0.03 & $0.66^{\mathrm{a}}$ \\
\hline B3 & 92 & 12.8 & 45 & $10-20$ & 20 & 0.80 & 0.15 & ND & ND \\
\hline B4 & 183 & 13.3 & 37 & 15 & 30 & 0.75 & 0.14 & 0.05 & $0.62^{\mathrm{a}}$ \\
\hline B5 & 915 & 16.5 & 42 & $10-25$ & 20 & 0.31 & 0.00 & 0.02 & $1.77^{\mathrm{a}}$ \\
\hline B6 & 1830 & 17.3 & 45 & $20-30$ & 40 & 0.36 & 0.03 & 0.03 & $0.88^{\mathrm{a}}$ \\
\hline \multicolumn{10}{|c|}{ Northern Edge } \\
\hline $\mathrm{C} 1$ & 46 & 11.6 & 24 & none & 10 & 2.40 & 0.11 & 0.06 & 0.86 \\
\hline $\mathrm{C} 2$ & 92 & 15.8 & 26 & 20 & $20-40$ & 0.75 & 0.01 & 0.01 & 0.13 \\
\hline $\mathrm{C} 3$ & 183 & 15.4 & 36 & $10-17$ & $20-40$ & 0.77 & 0.01 & 0.09 & $0.71^{\mathrm{a}}$ \\
\hline
\end{tabular}

For each ciliate species studied, 3 to 8 vials were wrapped in aluminum foil (dark controls) and from 5 to 30 vials were exposed to $100 \mu \mathrm{E} \mathrm{m}^{-2} \mathrm{~s}^{-1}$ irradiance provided by $20 \mathrm{~W}$ Sylvania cool white fluorescent bulbs. The vials were immersed in a water bath at ambient water temperature. Incubations were begun between 09:00 and 10:00 h. After 6h, contents of the vials were examined under a dissecting microscope, and vials containing a single, live ciliate processed further. At the end of the incubations, usually less than half of the vials to which we had added a single ciliate contained a live ciliate. Although loss of ciliate cells immediately after transfer is high, the cells which survive appear to be healthy and their rates of photosynthesis remain linear for 5 to $6 \mathrm{~h}$ (Stoecker et al. 1987a, Stoecker et al. 1988). Data are only shown for incubations in which there were at least 3 surviving 'dark' and 10 surviving 'light' replicates. To kill cells and remove inorganic ${ }^{14} \mathrm{C}, 2 \mathrm{ml}$ of $5 \%$ acetic acid in methanol were added to each vial and the vials were evaporated to dryness. Then, $1 \mathrm{ml}$ of distilled water was added to the vials, followed by $10 \mathrm{ml}$ of scintillation fluid (ScintiVerse II, Fisher Scientific).

Myrionecta rubra lacks a functional mouth (Lindholm 1985) and thus it was not necessary to incubate this species in the absence of algae to avoid uptake of labelled algal cells. Thirty-two $\mathrm{ml}$ polycarbonate centrifuge tubes, containing $30 \mathrm{ml}$ whole water samples rich in $M$. rubra, were spiked with an estimated $0.5 \mu \mathrm{Ci}$ $\mathrm{ml}^{-1}$ of ${ }^{14} \mathrm{C}$ bicarbonate, and then incubated as were the vials. At the end of the incubation, $M$. rubra were isolated from the incubated samples and washed twice; 2 cells were transferred to each scintillation vial and the vials were prepared for counting. Transfers of rinse water equivalent to that transferred with the ciliates produced background levels of activity.

To estimate community rates of photosynthesis, triplicate $3 \mathrm{ml}$ aliquots of the seawater sample were spiked with $0.5 \mu \mathrm{Ci} \mathrm{ml}{ }^{-1}$ of ${ }^{14} \mathrm{C}$ bicarbonate and incubated and processed in the same way as the vials containing only ciliates.

Samples were counted on a Minaxi b Tricarb 4000 Series liquid scintillation counter (United Technologies Packard) and the external standard ratio method was used to correct for quench. Uptake of ${ }^{14} \mathrm{C}$ due to photosynthesis was estimated by subtracting the average uptake in the dark from the uptake in the light. Rates of photosynthesis were calculated from light-mediated ${ }^{14} \mathrm{C}$ uptake as described in Parsons et al. (1984a).

\section{RESULTS}

\section{Survey of ciliates along Transects A, B, and C}

The 2 transects on the southern flank of Georges Bank crossed from cold ( 11 to $12^{\circ} \mathrm{C}$ ), unstratified waters on the bank to the edge of the slope where warmer (17 to $18^{\circ} \mathrm{C}$ ) waters overlay a well-developed thermocline (Table 1). Transect C, at the northern edge of Georges 


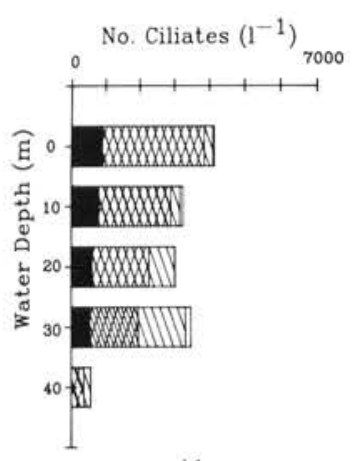

A1

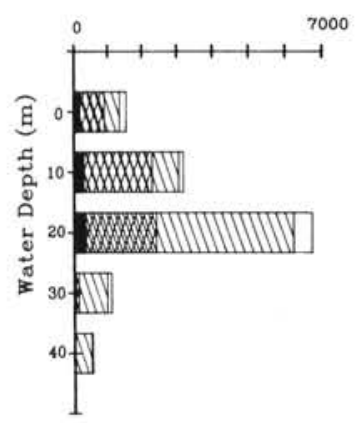

A3

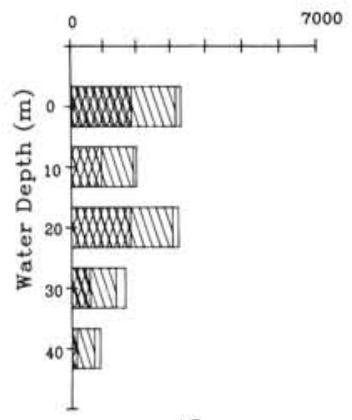

A5

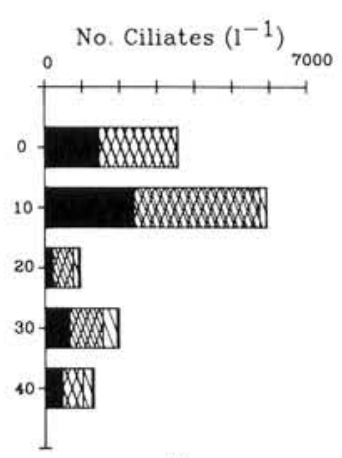

A2

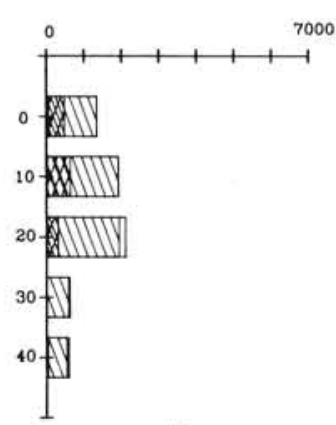

A4

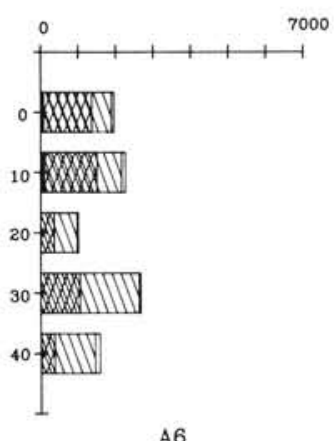

A6

Fig. 2. Vertical distribution of microplanktonic ciliates at stations on Transect A. Note changes in ciliate fauna from mixed bank water (A1) across the southern flank of Georges Bank to the edge of the continental shelf (A6). Black bars: Myrionecta rubra; cross-hatched bars: oligotrichs that retain algal chloroplasts; singly-hatched bars: strictly heterotrophic oligotrichs; open bars: tintinnids. Data not shown for other, rarer categories

Bank, crossed from mixed waters of the bank (C1) into the Gulf of Maine (C3) (Fig. 1). A visible tidal front was present just north of Station C1. The physical differences among stations were reflected in differences in inorganic nutrient availability, average chlorophyll concentrations, and the presence and depth of a chlorophyll maximum layer (Table 1). The differences among stations observed were similar to those reported

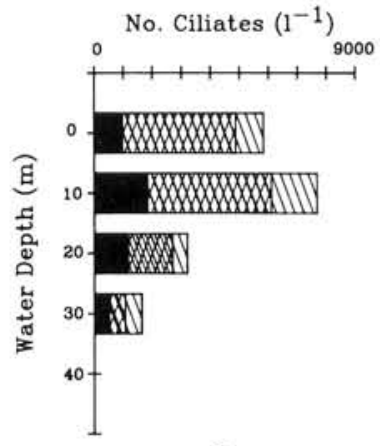

B1

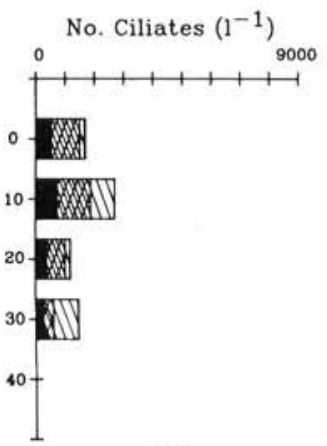

B2

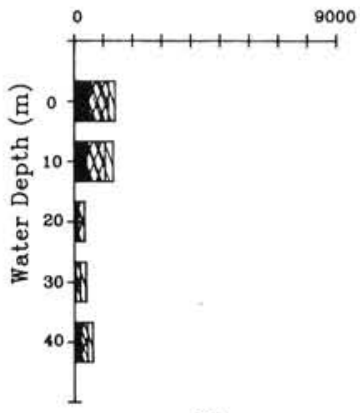

B3

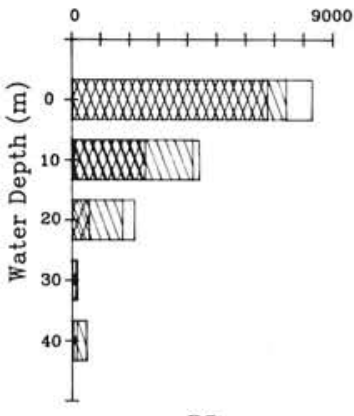

B5

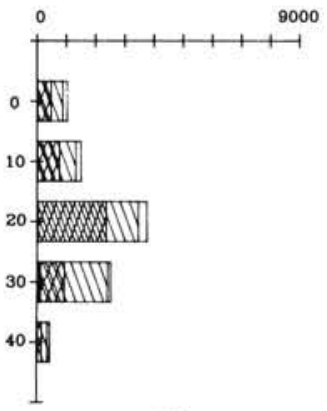

B4

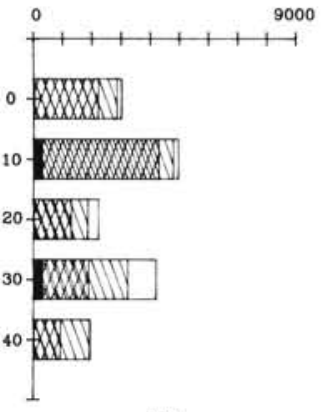

B6

Fig. 3. Vertical distribution of microplanktonic ciliates at stations on Transect B. Note changes in ciliate fauna from mixed bank water (B1) across the southern flank of Georges Bank to the edge of the continental shelf (B6). Data not shown for other, rarer categories. Column characteristics as in Fig. 2

by O'Reilly et al. (1987) for Georges Bank. Average chlorophyll values were higher on the bank than at stations in deeper water. At the stations on the southern flank of the Georges Bank, the water column was stratified with a thermocline and nutricline above the depth of the $1 \%$ light level.

The abundances of ciliates in the samples taken at discrete depths (Figs. 2 to 5) were used to calculate average integrated abundances for the euphotic zone (Table 2). Microplanktonic ciliate densities varied among stations from a low of 580 cells $1^{-1}$ at Station B3 to a high of 13000 cells $1^{-1}$ at Station C1, the average for all stations was 3000 cells $1^{-1}$. There was no clear relationship between bathymetry and ciliate abun- 


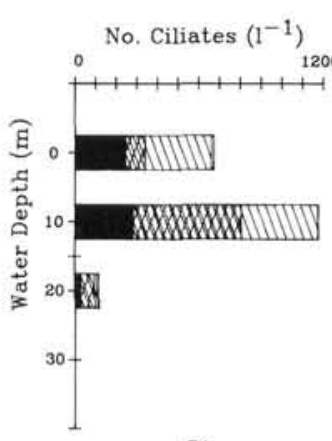

C1

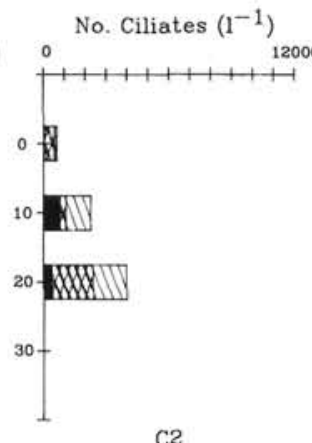

C2

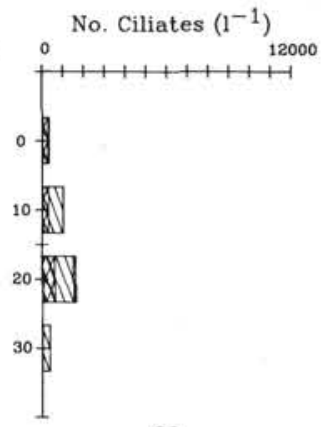

c3
Fig. 4. Vertical distribution of microplanktonic ciliates at stations on Transect C. Note change in ciliate fauna between station on the bank (C1) and station in the Gulf of Maine (C3). Data are not shown for other, rarer categories. Column characteristics as in Fig. 2 dance and the greatest abundance was found at the $192 \mathrm{~m}, 1830 \mathrm{~m}$ and $46 \mathrm{~m}$ stations along Transects $\mathrm{A}, \mathrm{B}$, and $C$, respectively.

Ciliates without overall chlorophyll (red) or phycoerythrin (orange) fluorescence were classified as strict heterotrophs. At all stations, the strictly heterotrophic ciliate fauna was dominated by oligotrichs (Table 2). Other types of non-loricate ciliates made up less than $3 \%$, and tintinnids made up less than $8 \%$ of the heterotrophic ciliate fauna (Table 2). All tintinnids in our samples were heterotrophic.
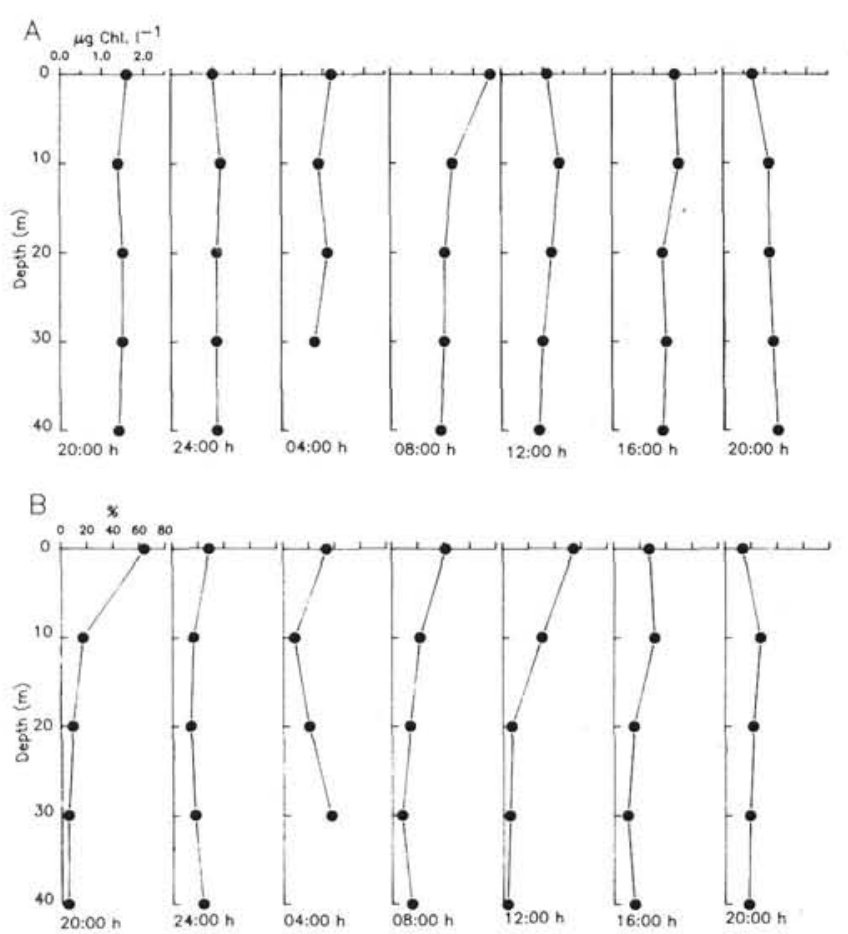

Myrionecta rubra was only abundant at stations within the $100 \mathrm{~m}$ isobath, where it numerically comprised, on average, about $30 \%$ of the ciliate fauna (Table 2). It was rare at the stations in deeper water. The integrated average density of $M$. rubra was positively correlated with the amount of chlorophyll in the euphotic zone (Fig. 6). At 11 out of the 15 stations, the average distribution of $M$. rubra was higher in the euphotic zone than was that of the heterotrophic ciliates (Fig. 2 to 4 ).

At Stations B2, B3, B6 and C3, we observed a 60 by
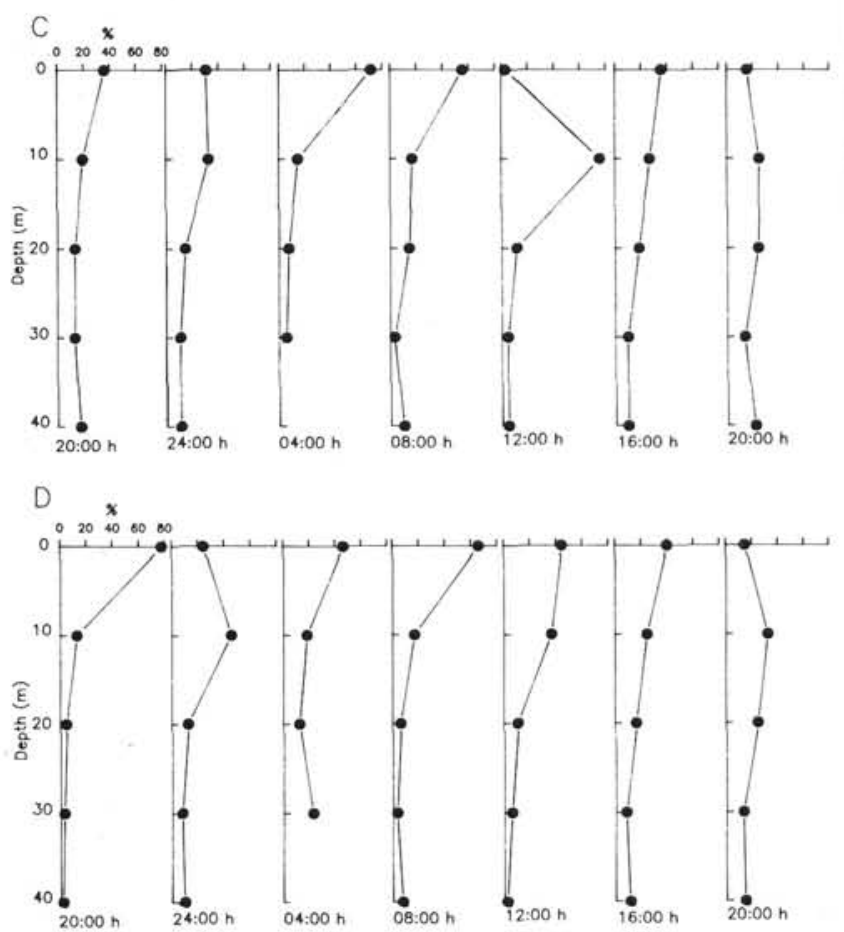

Fig. 5. Diel distribution pattern of chlorophyll a (A), Myrionecta rubra (B), Laboea strobila (C), and Strombidium spp. (D) with chloroplasts; drogue station (A1'), July 1 and 2, 1988. Ciliate abundance given as percent of total cells. No data for $40 \mathrm{~m}$ at $04: 00 \mathrm{~h}$. Sunrise was at 05:52 h, sunset at 21:08 h. Dependence of vertical distribution on sampling time was tested with $\mathrm{R} \times \mathrm{C}$ test of independence (Sokal \& Rohlf 1981). The $40 \mathrm{~m}$ samples were not included in this analysis because of the missing data point

\begin{tabular}{lcrc} 
Species & Mean count & $\mathrm{G}_{\text {adj }}$ & $p$ \\
\hline M. rubra & 205 & 1038 & $<0.001$ \\
L. strobila & 42 & 350 & $<0.001$ \\
Strombidium spp. & 234 & 1218 & $<0.001$
\end{tabular}


Table 2. Average numerical abundance (cells $\mathrm{l}^{-1}$ ) of microplankton ciliates integrated above the depth of the $1 \%$ light level

\begin{tabular}{|c|c|c|c|c|c|c|c|c|}
\hline \multirow[t]{2}{*}{ Station } & \multicolumn{4}{|c|}{ Species with chlorophyll } & \multicolumn{3}{|c|}{ Species without chlorophyll } & \multirow{2}{*}{$\begin{array}{c}\text { Total } \\
\text { all ciliates }\end{array}$} \\
\hline & M. rubra & L. strobila & $\begin{array}{l}\text { Tontonia } \\
\text { spp. }\end{array}$ & $\begin{array}{l}\text { Strom- } \\
\text { bidium } \\
\text { spp. }\end{array}$ & Oligotrichs & Tintinnids & Other & \\
\hline \multicolumn{9}{|c|}{ Southern Flank } \\
\hline A1 & 608 & 203 & 187 & 712 & 649 & 67 & 44 & 2470 \\
\hline $\mathrm{A} 2$ & 1051 & 228 & 19 & 233 & 201 & 40 & 7 & 1779 \\
\hline A3 & 186 & 312 & 314 & 343 & 1490 & 196 & 148 & 2989 \\
\hline A4 & 23 & 36 & 60 & 172 & 1042 & 74 & 10 & 1417 \\
\hline A5 & 8 & 49 & 547 & 476 & 991 & 177 & 26 & 2274 \\
\hline A6 & 40 & 6 & 314 & 551 & 910 & 69 & 19 & 1909 \\
\hline B1 & 1258 & 157 & 71 & 1182 & 944 & 7 & 60 & 3679 \\
\hline B2 & 505 & 147 & 11 & 150 & 494 & 14 & 4 & 1325 \\
\hline B3 & 298 & 52 & 8 & 44 & 171 & 8 & 0 & 581 \\
\hline B4 & 54 & 76 & 378 & 535 & 858 & 175 & 14 & 2090 \\
\hline B5 & 39 & 8 & 808 & 784 & 837 & 271 & 6 & 2753 \\
\hline B6 & 177 & 23 & 1305 & 578 & 2888 & 404 & 14 & 5389 \\
\hline \multicolumn{9}{|c|}{ Northern Edge } \\
\hline C1 & 2094 & 461 & 48 & 2498 & 7780 & 76 & 196 & 13153 \\
\hline $\mathrm{C} 2$ & 506 & 103 & 32 & 614 & 2275 & 7 & 59 & 3595 \\
\hline C3 & 25 & 64 & 21 & 247 & 962 & 35 & 37 & 1391 \\
\hline
\end{tabular}

$65 \mu \mathrm{m}$ non-oligotrichous ciliate, probably a Dinophrya sp. (family Didiniidae) (Sniezak pers. comm.). Each ciliate contained 10 to 20 oval, red epifluorescent bodies, which appeared to be algal cells. Since this species made up less than $1 \%$ of the ciliate fauna at all the stations and no data are available on its physiology, we did not include it in the data summaries (Tables 2 to 4).

At all stations we observed planktonic, oligotrichous ciliates with bright red or occasionally red and orange epifluorescence. The species with red fluorescence included Laboea strobila, Tontonia spp. and some Strombidium spp. (Table 2). All species observed were consistently either epifluorescent or non-epifluorescent, except for a small, round form about 15 to $20 \mu \mathrm{m}$ in size. It is possible that we were lumping 2 species into this one 'type'.

Laboea strobila was found at all stations, but was abundant only at stations inside of the $100 \mathrm{~m}$ isobath (Table 2). The average integrated density of this species was positively correlated with the amount of chlorophyll (Fig. 7). L. strobila numerically accounted for about $9 \%$ of the chlorophyll-containing ciliate fauna, but because of its large size (ca $81000 \mu \mathrm{m}^{3}$ for preserved specimens), it contributed an estimated $24 \%$ of the biomass (Table 4). Tontonia spp. were found at all stations, but the forms common on the bank and in the Gulf of Maine differed markedly in size and shape from those found at Stations A5, A6, B5, and B6. Overall, Tontonia spp. were most abundant at the stations near the edge of the continental slope (Table 2). Strombidium spp. with chlorophyll were abundant at all stations except for B3, which had a low ciliate density.

In the euphotic zone, oligotrichs that contained chlorophyll contributed 18 to $58 \%$ of the total microplanktonic ciliate fauna. They were abundant at both the mixed and stratified stations (Table 3 ). Neither their percent contribution to the total ciliate fauna nor their

Table 3. Percent numerical contribution of ciliates with chlorophyll to the microplanktonic ciliate fauna, integrated above the depth of the $1 \%$ light level

\begin{tabular}{|c|c|c|c|}
\hline Station & $\begin{array}{c}\text { M. rubra } \\
(\%)\end{array}$ & $\begin{array}{l}\text { Oligotrichs with } \\
\text { chloroplasts }^{\mathrm{a}}(\%)\end{array}$ & $\begin{array}{l}\text { Total } \\
(\%)\end{array}$ \\
\hline \multicolumn{4}{|c|}{ Southern Flank } \\
\hline $\mathrm{A} 1$ & 25 & 45 & 70 \\
\hline $\mathrm{A} 2$ & 59 & 27 & 86 \\
\hline A3 & 6 & 32 & 39 \\
\hline A4 & 2 & 19 & 21 \\
\hline A5 & $<1$ & 47 & 47 \\
\hline A6 & 2 & 46 & 48 \\
\hline B1 & 34 & 38 & 72 \\
\hline B2 & 38 & 23 & 61 \\
\hline B3 & 51 & 18 & 69 \\
\hline B4 & 3 & 47 & 50 \\
\hline B5 & 1 & 58 & 59 \\
\hline B6 & 3 & 35 & 38 \\
\hline \multicolumn{4}{|c|}{ Northern Edge } \\
\hline C1 & 16 & 23 & 39 \\
\hline $\mathrm{C} 2$ & 14 & 21 & 35 \\
\hline C3 & 2 & 24 & 26 \\
\hline
\end{tabular}



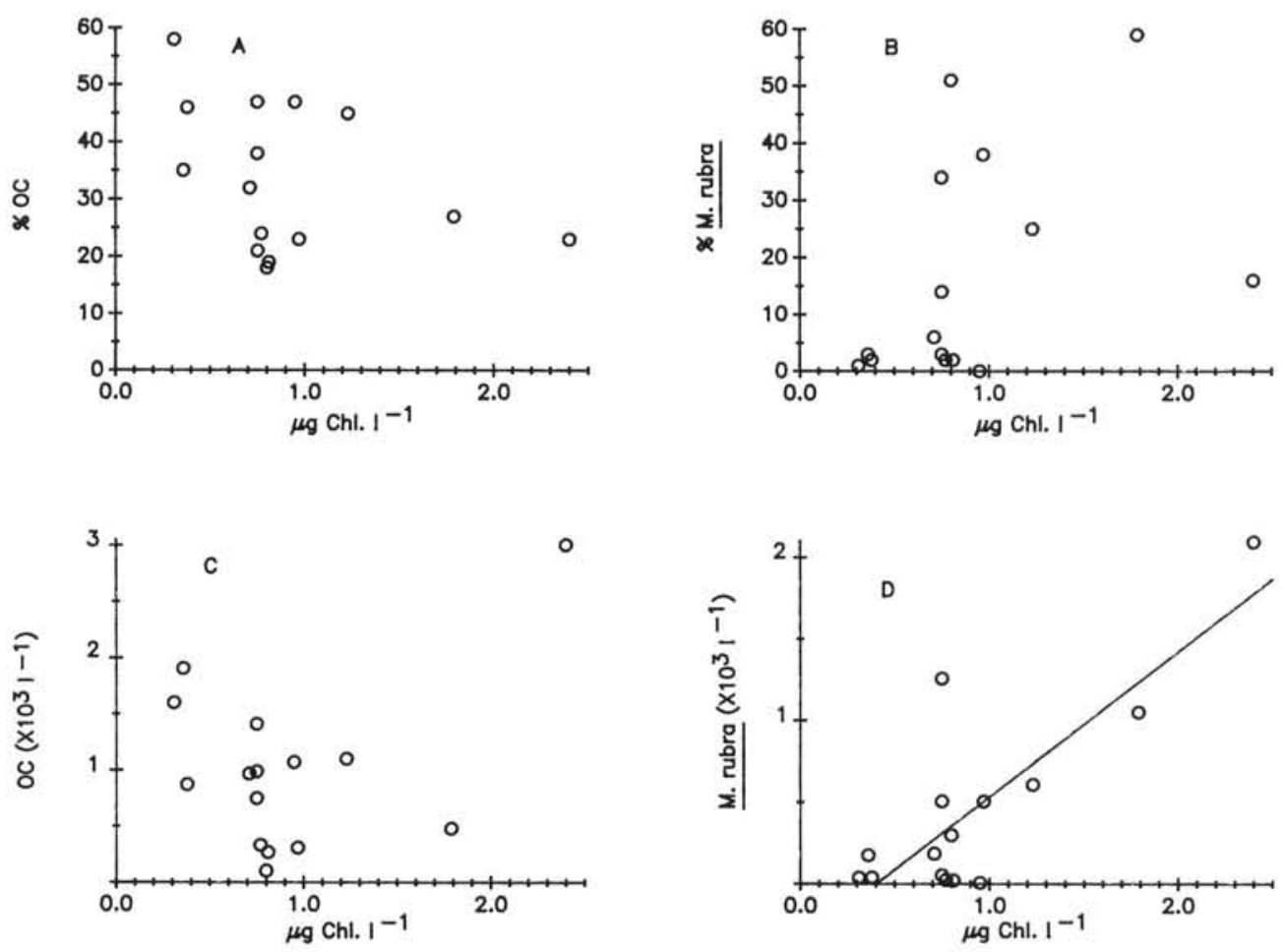

Fig. 6. Percent contributions of (A) oligotrichs with chlorophyll (OC), (B) Myrionecta rubra; both contributions to the microplanktonic ciliate fauna in the euphotic zone were not significantly correlated with chlorophyll concentration $(\mathrm{R}=0.37, \mathrm{R}=0.43$, respectively; for both $p>0.05$ ). Numerical abundance of oligotrichs with chlorophyll $(\mathrm{C})$ was not correlated with chlorophyll ( $\mathrm{R}=$ $0.34 ; p>0.05)$. Density of $M$. rubra (D) was positively correlated with chlorophyll $(\mathrm{R}=0.81 ; p>0.01)$. Integrated averages for the euphotic zone at each station

absolute numerical abundance was correlated with total chlorophyll (Fig. 6).

The estimated biomass of oligotrichs with chloroplasts was correlated with chlorophyll values in the euphotic zone (Fig. 8). Abundance of Laboea strobila, the species which contributed the most biomass, was positively correlated with chlorophyll (Fig. 7), and the

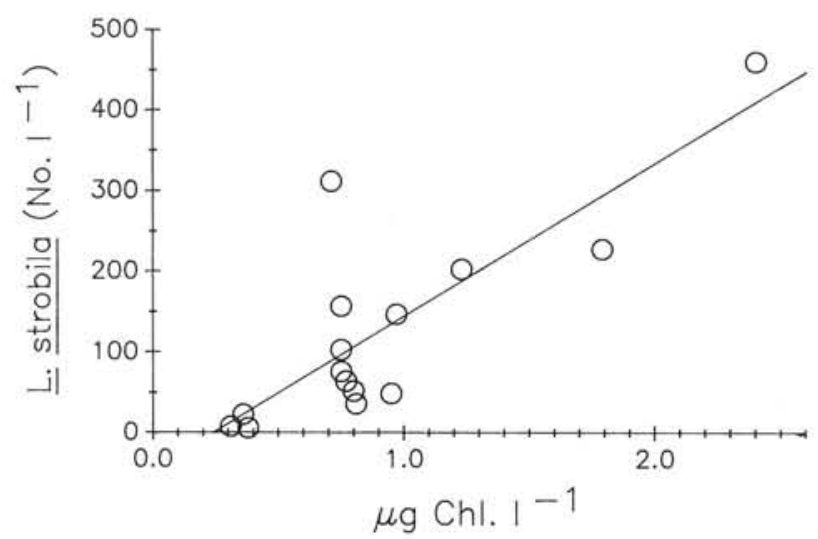

Fig. 7. Average concentration of Laboea strobila in the euphotic zone was positively correlated with chlorophyll values $(\mathrm{R}=$ $0.81 ; p<0.01)$. Integrated averages for the euphotic zone at each station correlation between total biomass and chlorophyll was probably mostly due to the distribution of this species. Oligotrichs with chloroplasts were found higher up in the euphotic zone than the strictly heterotrophic ciliates at all stations except C1 and C2 (Figs. 2 to 4).

We estimate that Myrionecta rubra plus the oligotrichs with chloroplasts had a biomass ranging from $<1.0 \mu \mathrm{g} \mathrm{Cl}^{-1}$ at Stations A4 and C3 to over $4.5 \mu \mathrm{g} \mathrm{Cl}{ }^{-1}$ in the unstratified, shallow waters on the bank (Stations A1, B1, C1) (Table 4). Our biomass estimates are probably low because of loss of ciliates during sampling and fixation (Gifford 1985) and the use of carbon:volume relationships for heterotrophic ciliates which may underestimate the carbon content of photosynthetic ciliates (Putt unpubl.).

\section{Drogue study of the diel vertical distribution of ciliates}

During the drogue study $(20: 00 \mathrm{~h}$ on 1 July to $20: 00 \mathrm{~h}$ on 2 July, 1987), there was almost no wind or sea and the sky was overcast part of the time. At noon, the irradiance just below the surface was about $1800 \mu \mathrm{E}$

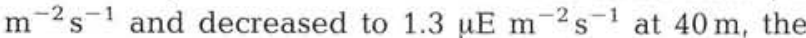


Table 4. Average biomass of ciliates with chlorophyll, integrated above depth of the $1 \%$ light level. Biomass values are minimum estimates

\begin{tabular}{|c|c|c|c|c|c|}
\hline \multirow[t]{2}{*}{ Station } & \multirow{2}{*}{$\begin{array}{l}\text { Est. biomass } \\
\left(\mu \mathrm{gC} 1^{-1}\right)\end{array}$} & \multicolumn{4}{|c|}{ Estimated proportion } \\
\hline & & $\begin{array}{c}\text { M. rubra } \\
(\%)\end{array}$ & $\begin{array}{c}\text { L. strobila } \\
(\%)\end{array}$ & $\begin{array}{c}\text { Tontonia spp. } \\
\qquad(\%)\end{array}$ & $\begin{array}{l}\text { Strombidium } \\
\text { spp. }(\%)\end{array}$ \\
\hline \multicolumn{6}{|c|}{ Southern Flank } \\
\hline $\mathrm{A} 1$ & 4.7 & 32 & 27 & 6 & 35 \\
\hline A2 & 5.0 & 57 & 3 & 1 & 40 \\
\hline A3 & 3.6 & 12 & 49 & 11 & 28 \\
\hline A4 & 0.7 & 10 & 29 & 11 & 50 \\
\hline A5 & 1.6 & 2 & 24 & 37 & 37 \\
\hline A6 & 1.8 & 6 & 2 & 19 & 73 \\
\hline B1 & 5.1 & 57 & 17 & 2 & 24 \\
\hline B2 & 2.5 & 53 & 37 & 1 & 9 \\
\hline B3 & 1.1 & 65 & 28 & 1 & 6 \\
\hline B4 & 1.7 & 8 & 26 & 23 & 43 \\
\hline B5 & 1.7 & 6 & 3 & 65 & 26 \\
\hline B6 & 2.5 & 17 & 6 & 50 & 27 \\
\hline \multicolumn{6}{|c|}{ Northern Flank } \\
\hline C1 & 7.3 & 36 & 37 & 1 & 26 \\
\hline $\mathrm{C} 2$ & 3.4 & 34 & 25 & 2 & 40 \\
\hline $\mathrm{C} 3$ & 0.7 & 7 & 48 & 3 & 42 \\
\hline
\end{tabular}

depth of our deepest samples (Table 5). The drogue followed a counterclockwise path and remained between the 45 and $55 \mathrm{~m}$ isobaths on the Bank during the entire $24 \mathrm{~h}$ period. The water column was isother$\mathrm{mal}$ and isohaline except during the day when the top 3 to $5 \mathrm{~m}$ were about $1 \mathrm{C}^{\circ}$ warmer than the underlying waters. This slight thermocline broke down at night. For the 7 sampling times, the average integrated chlorophyll content was $1.24 \mu \mathrm{g} \mathrm{Chla} 1^{-1}(\mathrm{SD}, 0.22)$ (Fig. 5a).

The vertical distributions of Myrionecta rubra, Laboea strobila, and of Strombidium spp. with chloro-

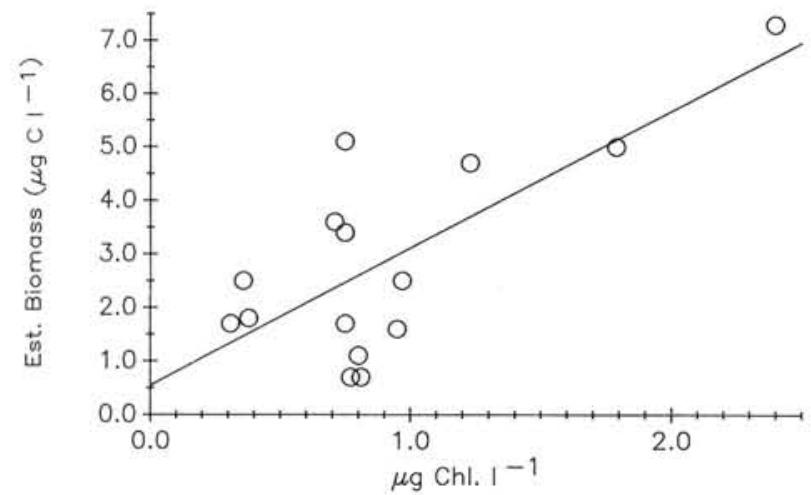

Fig. 8. Estimated biomass of ciliates with chorophyll (oligotrichs and Myrionecta rubra) in the euphotic zone was positively correlated with chlorophyll $(\mathrm{R}=0.73 ; p<0.01) ; y$ intercept was not significantly different from $0 ; p>0.05$. Integrated averages for the euphotic zone at each station. Biomass estimates are minimum estimates plasts changed during the day (Fig. $5 \mathrm{~b}$ to d). However, since the samples were taken at discrete depths, it is possible that we missed some abundance peaks. We have no evidence for large migrations of these species out of the euphotic zone, although their vertical distributions did become more even at night. This may have been due to diurnal mixing patterns. At 20:00 h, over $50 \%$ of the M. rubra were found at the surface on the first day but not on the second. At noon, they were also most abundant at the surface. At other times, $M$. rubra was more evenly distributed in the water column (Fig. 5b).

In Laboea strobila the diel pattern was different. This species was concentrated near the surface just before sunrise $(04: 00 \mathrm{~h}$ sample) and at $08: 00 \mathrm{~h}$, but had a subsurface maximum at noon (Fig. 5c). As a group, the Strombidium spp. with chlorophyll had a distribution

Table 5. Diel distribution of irradiance $\left(\mu \mathrm{E} \mathrm{m}^{-2} \mathrm{~s}^{-1}\right)$ during diel drogue study at Station A1'

\begin{tabular}{cccccccc}
$\begin{array}{c}\text { Depth } \\
(\mathrm{m})\end{array}$ & 1 Jul & 1 Jul & 2 Jul & 2 Jul & 2 Jul & 2 Jul & 2 Jul \\
\hline & $24: 00$ & $04: 00$ & $08: 00$ & $12: 00$ & $16: 00$ & $20: 00$ \\
\hline 0 & 2 & - & - & 180 & 1800 & 450 & $<2$ \\
10 & 0.2 & - & - & 22 & 230 & 47 & - \\
20 & - & - & - & 6 & 45 & 9.5 & - \\
30 & - & - & - & 1.5 & 6 & 21 & - \\
40 & - & - & - & 0.2 & 1.3 & 0.4 & - \\
& & & & & & &
\end{tabular}


Table 6. Chlorophyll content and estimated rates of photosynthesis in surface water incubations (6 h, ambient water temperature, $100 \mu \mathrm{E} \mathrm{m}^{-2} \mathrm{~s}^{-1}$ irradiance). Means (SD)

\begin{tabular}{|c|c|c|c|c|c|c|}
\hline \multirow[t]{2}{*}{ Station } & \multirow[t]{2}{*}{ Temp $\left({ }^{\circ} \mathrm{C}\right)$} & \multicolumn{2}{|c|}{$\mu \mathrm{g} \mathrm{Chl} \mathrm{a} \mathrm{l}^{-1}$} & \multirow{2}{*}{$\begin{array}{l}\text { Est. } \% \text { Chl a } \\
\quad \geq 20 \mu \mathrm{m}\end{array}$} & \multicolumn{2}{|c|}{ Rate of photosynthesis } \\
\hline & & Total & $<20 \mu \mathrm{m}$ & & $\mu \mathrm{gC} \mathrm{l}^{-1} \mathrm{~h}^{-1}$ & $\mu \mathrm{gC}(\mu \mathrm{g} \mathrm{chl})^{-1} \mathrm{~h}^{-1}$ \\
\hline A1 & 11 & $0.62(0.03)$ & $591(31)$ & 5 & $3.41(0.67)$ & 5.5 \\
\hline $\mathrm{A} 1^{\mathrm{a}}$ & 11 & $0.68(0.12)$ & $453(164)$ & 33 & $3.61(0.24)$ & 5.3 \\
\hline B1 & 12 & $0.37(0.04)$ & $296(23)$ & 20 & $0.51(0.13)$ & 1.4 \\
\hline $\mathrm{C} 1$ & 12 & $1.08(0.16)$ & $925(180)$ & 14 & $6.20(0.33)$ & 5.6 \\
\hline C3 & 14 & $0.14(0.00)$ & $136(14)$ & 4 & $0.20(0.05)$ & 1.4 \\
\hline
\end{tabular}

pattern somewhat similar to that of Myrionecta rubra (Fig. 5a, d); Strombidium were concentrated near the surface in the $20: 00 \mathrm{~h}$ sample on July 1 but not on July 2, and during the morning tended to be most abundant in the surface samples.

\section{Photosynthesis experiments}

Photosynthesis in the surface whole water samples varied from 0.2 (Station C3) to $3.6 \mu \mathrm{g} \mathrm{Cl}^{-1} \mathrm{~h}^{-1}$ (Station A1': drogue station) under our incubation conditions (Table 6). The proportion of chlorophyll in the microplankton fraction varied from 5 to $33 \%$ (Table 6).

In the single cell uptake experiments, we focused on the larger species, Laboea strobila and Myrionecta rubra, because these cells could be recognized to species under the dissecting microscope and because these 2 species combined usually made up over $50 \%$ of the biomass of pigmented ciliates at the shallower stations (Table 4). The photosynthetic rates of $L$. strobila in 2 incubations were not statistically different, the average rate was $465 \mathrm{pg} \mathrm{C}$ fixed cell ${ }^{-1} \mathrm{~h}^{-1}$ (Table 7 ). M. rubra had a photosynthetic rate of $85 \mathrm{pg} C$ fixed cell ${ }^{-1} \mathrm{~h}^{-1}$.

The surface water samples used for the incubations varied in their ciliate fauna (Table 8). Based on the

Table 7. Single cell ${ }^{14} \mathrm{C}$ uptake experiments with ciliates from surface water samples; incubation conditions were same as for whole assemblages (refer to Table 6). Means (SD)

\begin{tabular}{|lccc|}
\hline Species & Station & $N$ & $\begin{array}{c}\text { Rate of photosynthesis } \\
\left(\mathrm{pg} \mathrm{C} \text { cell }^{-1} \mathrm{~h}^{-1}\right)\end{array}$ \\
\hline I. Myrionecta rubra & B1 & 21 & $85(33)$ \\
II. Laboea strobila & A1 & 12 & $559(88)^{\mathrm{a}}$ \\
& B1 & 15 & $371(104)$ \\
a The 2 rates for Laboea strobila are not significantly differ- \\
ent $(p>0.05$, single classification Analysis of Variance). \\
Mean of the 2 rates is 465 pg C cell ${ }^{-1} \mathrm{~h}^{-1}$ \\
\hline
\end{tabular}

concentration of Laboea strobila and Myrionecta rubra in the samples and the average uptake rates in the single cell incubations, we have made rough estimates of the potential contribution of these 2 species to photosynthesis (Table 8). Because the ratio of production to biomass (or chlorophyll) is often higher in $<20 \mu \mathrm{m}$ than in $>20 \mu \mathrm{m}$ phytoplankton (Malone 1980, O'Reilly et al. 1987), the microplankton contribution to photosynthesis should be overestimated but the proportional contribution of ciliates to photosynthesis within this size fraction underestimated in Table 8 . The relative contribution of ciliates to primary production appeared to be quite variable among samples. We estimate that under our incubation conditions $\left(100 \mu \mathrm{E} \mathrm{m}^{-2} \mathrm{~s}^{-1}\right.$; ambient surface water temperature; $6 \mathrm{~h}$ incubation), $M$. rubra and L. strobila together contributed 1 to $7 \%$ of the total carbon fixed and 14 to $90 \%$ of the carbon fixed by the microplankton fraction.

\section{DISCUSSION}

At least during early summer, and perhaps at other times as well, ciliates with chlorophyll are an important component of the microplankton on the continental shelf and in slope waters off Massachusetts, USA. On Georges Bank proper, the photoautotrophic ciliate Myrionecta rubra occurred at densities of 1 to $2 \times 10^{3}$ cells $1^{-1}$. These densities are similar to those routinely reported for this species in coastal waters (McManus \& Fuhrman 1986, Dale 1987) and in the Gulf of Maine (Montagnes \& Lynn unpubl.), although densities several orders of magnitude higher have been reported during 'blooms' (reviewed in Lindholm 1985). M. rubra was an important component of the ciliate fauna on the bank during our survey, contributing an estimated 12 to $65 \%$ of the ciliate biomass in the euphotic zone (Table 4).

Blooms of Myrionecta rubra make an important contribution to primary productivity in upwelling ecosystems (Smith \& Barber 1979, see also review by Lindholm 1985). During blooms, maximum rates of 
Table 8. Abundance of ciliates with chlorophyll in surface water incubations, and their estimated contribution to total photosynthesis and to photosynthesis in the microplankton $(\geq 20 \mu \mathrm{m})$ size fraction

\begin{tabular}{|c|c|c|c|c|c|c|c|c|}
\hline \multirow[t]{2}{*}{ Station } & \multicolumn{3}{|c|}{ Cells I ${ }^{-1}$} & \multicolumn{3}{|c|}{ Est. ng C fixed $\mathrm{l}^{-1} \mathrm{~h}^{-1 \mathrm{a}}$} & \multicolumn{2}{|c|}{$\begin{array}{l}\text { Est. \% contribution to } \\
\text { photosynthesis of } M \text {. rubra and } \\
\text { L. strobila combined }\end{array}$} \\
\hline & M. rubra & L. strobila & Other spp. & M. rubra & L. strobila & Other spp. & Total & Microplankton \\
\hline A1 & 338 & 44 & 512 & 29 & 20 & ND & 1 & 29 \\
\hline $\mathrm{A} 1^{\cdot \mathrm{c}}$ & 839 & 207 & 1297 & 71 & 96 & ND & 5 & 14 \\
\hline B1 & 371 & 0 & 65 & 32 & 0 & ND & 6 & 31 \\
\hline $\mathrm{C} 1$ & 828 & 153 & 1263 & 70 & 71 & ND & 2 & 16 \\
\hline $\mathrm{C} 3$ & 0 & 32 & 8258 & 0 & 15 & ND & 7 & $\geq 90$ \\
\hline \multicolumn{9}{|c|}{$\begin{array}{l}\text { a Based on estimated rates of } 85 \mathrm{pg} \mathrm{cell}^{-1} \mathrm{~h}^{-1} \text { for Myrionecta rubra and } 465 \mathrm{pg} \mathrm{cell}^{-1} \mathrm{~h}^{-1} \text { for Laboea strobila (see Table } 7 \text { ) } \\
{ }^{\mathrm{b}} \text { Based on data in Table } 6 \text {. Photosynthesis by microplankton size fraction was estimated as: (\% chl a } \geq 20 \mu \mathrm{m} \text { ) (rate of } \\
\text { photosynthesis for whole water sample) } \\
{ }^{c} \text { A1: drogue station } \\
\text { ND: no data }\end{array}$} \\
\hline
\end{tabular}

photosynthesis are as high as $2187 \mu \mathrm{g} \mathrm{Cl}^{-1}$, and specific rates of photosynthesis are as high as $16.8 \mathrm{pg} \mathrm{C}$ (pg chla) $)^{-1} \mathrm{~h}^{-1}$ (Smith \& Barber 1979). The single cell technique allowed us to measure ${ }^{14} \mathrm{C}$ uptake rate per cell and to study photosynthesis in $M$. rubra under nonbloom conditions. In our $6 \mathrm{~h}$ incubation, we found a photosynthetic rate of $85 \mathrm{pg} \mathrm{C}$ cell ${ }^{-1} \mathrm{~h}^{-1}$. In blooms of M. rubra, light-saturated photosynthesis occurs at about $50 \%$ of incident light (Smith \& Barber 1979), and thus it is likely that we would have found a higher rate of photosynthesis in our incubations if we had used a higher irradiance. M. rubra is very sensitive to containment, and thus it is also possible that we would have observed a higher fixation rate if a shorter incubation time than $6 \mathrm{~h}$ had been used (Lindholm 1985). Rates of photosynthesis in this species are thought to be quite variable and to be highly influenced by diel cycles as well as by inorganic nutrient availability. In addition, populations of this species vary in their average cell size (Montagnes \& Lynn unpubl.), and this undoubtedly influences the photosynthetic capacity per cell. Before we can understand the role of $M$. rubra in coastal ecosystems, we need more data on its rate of photosynthesis under non-bloom conditions.

The oligotrichous ciliates with chlorophyll are physiologically different from Myrionecta rubra. Most of the marine, pigmented oligotrichs that have been examined by transmission electron microscopy have been found to contain isolated algal chloroplasts rather than algal endosymbionts (Blackbourn et al. 1973, Laval-Peuto et al. 1986, Jonsson 1987a, Stoecker \& Silver 1987). Based on light microscopy, pigmented forms with algal endosymbionts are sometimes reported, but these reports need to be confirmed by

Table 9. Reported frequency of chloroplast-retention among microplanktonic ciliates

\begin{tabular}{|c|c|c|c|c|}
\hline Location & Depth & Season & $\%$ of ciliate fauna & Source \\
\hline Woods Hole & 0 & $\begin{array}{l}\text { Spring } \\
\text { Summer } \\
\text { Fall } \\
\text { Winter }\end{array}$ & $\begin{array}{l}51^{\mathrm{a}} \\
47 \\
22 \\
22\end{array}$ & Stoecker et al. (1987a) \\
\hline Nantucket Sound & $\begin{array}{l}\text { Integrated; } \\
0-9 \mathrm{~m}\end{array}$ & $\begin{array}{l}\text { Early } \\
\text { summer }\end{array}$ & $48 ; 65^{\mathrm{a}}$ & Stoecker et al. (1987a) \\
\hline $\begin{array}{l}\text { Mediterranean Sea } \\
\text { (nearshore) }\end{array}$ & 0 & Fall \& winter & $41^{\mathrm{b}}$ & $\begin{array}{l}\text { Laval-Peuto \& } \\
\text { Rassoulzadegan (1988) }\end{array}$ \\
\hline Georges Bank & $\begin{array}{l}\text { Integrated } \\
0 \text { - depth } \\
\text { of } 1 \% \text { light level }\end{array}$ & $\begin{array}{l}\text { Early } \\
\text { summer }\end{array}$ & $39^{a}$ & This study \\
\hline
\end{tabular}


electron microscopy (Burkholder et al. 1967, Jonsson 1987a). The chloroplast-retaining oligotrichs, which appear to be the dominant type of photosynthetic oligotrichs in the marine plankton, are mixotrophic (Laval-Peuto et al. 1986, Jonsson 1987a, Stoecker et al. 1987a, Stoecker et al. 1988).

Most reports of oligotrichs that retain chloroplasts have been from neritic waters (Blackbourn et al. 1973, McManus \& Fuhrman 1986, Jonsson 1987a, Stoecker et al. 1987a, Laval-Peuto \& Rassoulzadegan 1988, Montagnes et al. 1988). Our data indicate that these mixotrophic ciliates are, at times, abundant in continental shelf and slope waters in the north Atlantic.

The ciliate species composition on Georges Bank proper was similar to that which we have observed nearshore (Stoecker et al. 1987a). The ciliate fauna at the edge of the slope (Stations A6 and B6) was very different from that on the bank proper (Table 2), but the proportion of oligotrichs that had chloroplasts was very similar (Table 3). Net phytoplankton populations on the bank are also different from those in the slope waters, the former are dominated by diatoms, the latter by dinoflagellates and coccolithophorids (Cura 1987). Overall, the pigmented oligotrichs accounted for $34 \%$ of the total ciliate fauna and about $39 \%$ of the choreotrichs (oligotrichs plus tintinnids) in the euphotic zone. The frequency of chloroplast-retention among ciliates in the Georges Bank area is comparable to that reported from temperate and subtropical neritic areas (Table 9). However, it is likely that during the winter the proportion of ciliates with chloroplasts decreases as it does in nearshore waters at the same latitude (Table 9).

At an irradiance of $100 \mu \mathrm{E} \mathrm{m}{ }^{-2} \mathrm{~s}^{-1}$, Laboea strobila had an average rate of photosnythesis similar to that expected at the same light intensity in cultured specimens of this species (Stoecker et al. 1988). Based on an observed range in chlorophyll content of 100 to $500 \mathrm{pg}$ chl cell ${ }^{-1}$ for cultured specimens (Stoecker et al. 1988 and unpubl.), the specific rate of photosynthesis of Laboea in the shipboard experiments is estimated to range from 0.9 to $4.6 \mathrm{pg} \mathrm{C}(\mathrm{pg} \mathrm{chl} \mathrm{a})^{-1} \mathrm{~h}^{-1}$ at $100 \mu \mathrm{E}$ $\mathrm{m}^{-2} \mathrm{~s}^{-1}$ (Table 7). Community specific rates varied from 1.4 to $5.5 \mathrm{pg} \mathrm{C}$ (pg chl a) $)^{-1} \mathrm{~h}^{-1}$ under the same incubation conditions (Table 6).

Because of differences in photoadaptation among cells, it is likely that our estimates of the proportional contribution of ciliates to photosynthesis would have been different if we had exposed the cells to different irradiances. The irradiance we chose, $100 \mu \mathrm{E} \mathrm{m}^{-2} \mathrm{~s}^{-1}$, is about $6 \%$ of the maximum surface irradiance (Table 5 ), and was probably light-limiting (Smith \& Barber 1979, Stoecker et al. 1988, Stoecker et al. unpubl.). However, this irradiance is within the range of average irradiances for the mixed layer on Georges Bank during the day
(Table 5). Our estimates of the contribution of ciliates to total primary production agree well with those of McManus \& Fuhrman (1986). However, the estimated combined contribution of Myrionecta rubra and Laboea strobila to microplankton primary productivity ranged from 14 to over $50 \%$ (Table 8). All these estimates of percent contribution are rough because the ratio of photosynthesis to chlorophyll may vary with phytoplankton cell size and/or taxon (Malone 1980), size fractionation is not accurate, greater than $20 \mu \mathrm{m}$ cells may go through a $20 \mu \mathrm{m}$ mesh (this is particularly true for the oligotrichs), and 15 to $20 \mu \mathrm{m}$ cells were included in the ciliate counts. Chlorophyll-containing ciliates other than M. rubra and L. strobila were present in the incubations (Table 8), and thus the total contribution of ciliates to photosynthesis by the microplankton fraction was probably greater than the contribution of just the 2 dominant species.

A rough estimate of the contribution of ciliates to the chlorophyll content in the euphotic zone can be made from carbon to chlorophyll ratios. In our samples, the average ratio of photosynthetic ciliate carbon to total chlorophyll was calculated to be about 2.6 (Fig. 8). Carbon to chlorophyll ratios in natural phytoplankton assemblages can be quite variable, but for 'healthy' plankton assemblages, the ratio is usually about 30 (Parsons et al. 1984b). Based on these ratios, we estimate that about $9 \%$ of the total chlorophyll may be accounted for by ciliates.

The vertical distribution of ciliates with chloroplasts on Georges Bank was similar to those that have been reported elsewhere (Lindholm 1985, McManus \& Fuhrman 1986, Dale 1987, Stoecker et al. 1987a). Myrionecta rubra appears to be able to regulate its position in the water column (Figs. 2 to 5 ). The preferred irradiance of $M$. rubra is about 10 to $50 \%$ of full sunlight and, on bright days, it is usually concentrated a few meters below the surface (Lindholm 1985). During our survey, it was usually most concentrated in the $10 \mathrm{~m}$ sample. The distribution of $M$. rubra changed during the diel cycle, it accumulated near the surface in the morning and descended in the afternoon (Fig. 5b). This pattern is consistent with the reported change in phototaxis of this species from positive in the morning to negative in the afternoon (Lindholm 1985).

The oligotrichous ciliates with chloroplasts also regulate their position in the water column. In our survey, they were usually located in the upper half of the euphotic zone during the day (Figs. 2 to 4 ) and showed diel changes in distribution pattern (Fig. 5c, d). Similar diel patterns were observed during 2 diel studies done in Nantucket Sound (Stoecker unpubl.). The observed patterns may be due both to ciliate behavior and diel mixing patterns. For example, Laboea strobila was concentrated near the surface at 
08:00 h, but by $12: 00 \mathrm{~h}$ it was about equally abundant at the surface and at $10 \mathrm{~m}$ (Fig. 5c); thus, it seems to occur most frequently at irradiances $\geq 180$ but $<1800 \mu \mathrm{E}$ $\mathrm{m}^{-2} \mathrm{~s}^{-1}$. In culture, maximum rate of photosynthesis and of growth occurs at irradiances between the 2 values (Stoecker et al. 1988 and unpubl.), and it is possible that the migratory behavior of these ciliates helps to maximize photosynthesis and growth. It is interesting that Myrionecta rubra, L. strobila, and Strombidium sp. with chloroplasts tended to ascend toward the surface before dawn (Fig. 5).

Our limited data suggest that during summer autotrophic and mixotrophic ciliates may account for a substantial proportion of photosynthesis in the microplankton size class in the upper euphotic zone. This raises several questions about the advantages that ciliates may have over microphytoplankton. The ecological success of Myrionecta rubra is probably due to a combination of its locomotory behavior and its autotrophic capacities. In stratified waters, it can exploit nutrient rich waters below the pycnocline as well as light in the euphotic zone. Packard et al. (1978) have suggested that $M$. rubra can remain in upwelling systems or along frontal boundaries where less motile organisms would wash out because of its behaviorial responses and its swimming speed, 2 to $7 \mathrm{~m} \mathrm{~h}^{-1}$ (Smith \& Barber 1979). Like M. rubra, oligotrichs have an advantage over non-motile microphytoplankton in having some control over their position in the water column. Under stratified and, or, low inorganic nutrient conditions, pigmented oligotrichs have another advantage; they probably obtain their inorganic nutrients through ingestion of other cells. Both $M$. rubra and photosynthetic oligotrichs - by exploiting nitrogen resources or habitats not available to most phytoplankton-may increase the efficiency with which large size cells are produced in coastal and shelf ecosystems.

Microplankton are within the size range of particles readily consumed by many zooplankton (Nival \& Nival 1976, reviewed in Conover 1982 and Sherr et al. 1986) and ciliates, in particular, are preferred over phytoplankton of similar size by some macrozooplankters (Stoecker \& Egloff 1987, Stoecker et al. 1987b, c). Autotrophic and mixotrophic photosynthetic ciliates are an important component of the microplankton in continental shelf and slope waters. Although ciliates probably make only a minor contribution to total primary production, their production may, at times, make an important contribution to food webs in shelf/slope ecosystems.

Acknowledgements. We thank Y. Coursey, J. Sniezak and M. Levandowsky, and the crew of the 'Oceanus' for help with sampling; R. Geyer, for the drogue; R. Olson and E. Zettler, for letting us use the inorganic nutrient data; L. H. Davis, for assisting in the analyses of samples; and Sand Dollar Electronics, for loaning the Seacat Profiler. We thank M. Putt, F. G. Carey, C. S. Davis, G. B. McManus, R. Olson, E. Sherr and E. Zettler for their comments. This research was supported by NSF grant OCE-860765 to D.K.S. Contribution No. 6789 from the Woods Hole Oceanographic Institution.

\section{LITERATURE CITED}

Blackbourn, D. J., Taylor, F. J. R., Blackbourn, J. (1973). Foreign organelle retention by ciliates. J. Protozool. 20: 286-288

Beers, J. R., Stewart, G. L. (1969). Microzooplankton and its abundance relative to the larger zooplankton and other seston components. Mar. Biol. 4: 182-189

Bigelow, H. B., Lillick, L. C., Sears, M. (1940). Phytoplankton and planktonic protozoa of the offshore waters of the Gulf of Maine: Part I, numerical distribution. Transactions of the American Philosophical Society 31 (pt. 3): 149-191

Burkholder, P. R., Burkholder, L. M., Almodovar, L. R. (1967). Carbon assimilation of marine flagellate blooms in neritic waters of southern Puerto Rico. Bull. mar. Sci. 17: 1-15

Cohen, E. B., Grosslein, M. D. (1987). Production on Georges Bank compared with other shelf ecosystems. In: Backus, R. H. (ed.) Georges Bank. M.I.T. Press, Boston, p. 383-391

Conover, R. J. (1982). Interrelations between microzooplankton and other plankton organisms. Ann. Inst. océanogr. Paris 58 (S): $31-46$

Cura, J. J., Jr (1987). Phytoplankton. In: Backus, R. H. (ed.) Georges Bank. M.I.T. Press, Boston, p. 213-218

Dale, T. (1987). Diel vertical distribution of planktonic ciliates in Lindaspollene, western Norway. Mar. microbial Food Webs 2: $15-28$

Dale, T., Dahl, E. (1987). Mass occurrence of planktonic oligotrichous ciliates in a bay in southern Norway. J. Plankton Res. 9: 871-879

Gieskes, W. W. C., Kraay, G. W. (1983). Dominance of Cryptophyceae during the phytoplankton spring bloom in the central North Sea detected by HPLC analysis of pigments. Mar. Biol. 75: 179-185

Gifford, D. J. (1985). Laboratory culture of marine planktonic oligotrichs (Ciliophora, Oligotrichida). Mar. Ecol. Prog. Ser. 23: 257-267

Jonsson, P. R. (1987a). Photosynthetic assimilation of inorganic carbon in marine oligotrich ciliates (Ciliophora, Oligotrichina). Mar. microbial Food Webs 2: 55-68

Jonsson, P. R. (1987b). Particle size selection, feeding rates and growth dynamics of marine planktonic oligotrichous ciliates (Ciliophora: Oligotrichina). Mar. Ecol. Prog. Ser. 33: 265-277

Kahl, A. (1932). Urtiere oder Protozoa I. Wimpertiere oder Ciliata (Infusoria). 3. Spirotricha. In: Dahl, F. (ed.) Die Tierwelt Deutschlands und der angrenzenden Meeresteile, Vol. 25. Gustav Fischer, Jena, p. 399-650

Laval-Peuto, M., Salvano, P., Gayol, P., Greuet, C. (1986). Mixotrophy in marine planktonic ciliates: ultrastructural study of Tontonia appendiculariformis (Ciliophora, Oligotrichina). Mar. microbial Food Webs 1: 81-104

Laval-Peuto, M., Rassoulzadegan, F. (1988). Autofluorescence of marine planktonic Oligotrichina and other ciliates. Hydrobiologia 159: 99-110

Lindholm, T. (1985). Mesodinium rubrum - a unique photosynthetic ciliate. Adv. aquat. Microbiol. 3: 1-48

Maeda, M., Carey, P. G. (1985). An illustrated guide to the species of the family Strombidiidae (Oligotrichida), free 
swimming protozoa common in aquatic environment. Bull. Ocean Res. Inst. Univ. Tokyo 19: 1-68

Malone, T. (1980). Algal size. In: Morris, I. (ed.) The physiological ecology of phytoplankton. Univ. of California Press, Berkeley, p. 433-463

McManus, G. B., Fuhrman, J. A. (1986). Photosynthetic pigments in the ciliate Laboea strobila from Long Island Sound, USA. J. Plankton Res. 8: 317-327

Montagnes, D. J. S., Lynn, D. H., Roff, J. C., Taylor, W. D. (1988). The annual cycle of heterotrophic planktonic ciliates in the waters surrounding the Isles of Shoals, Gulf of Maine: an assessment of their trophic role. Mar. Biol. 99: $21-30$

Montagnes, D. J. S., Lynn, D. H., Stoecker, D. K., Small, E. B. (1988). Taxonomic descriptions of one new species and rediscription of four species in the family Strombidiidae (Ciliophora, Oligotrichida). J. Protozool. 35: 189-197

Nival, P., Nival, S. (1976). Particle retention efficiencies of an herbivorous copepod, Acartia clausi (adult and copepodite stages): effects on grazing. Limnol. Oceanogr. 21: 24-38

O'Reilly, J. E., Evans-Zetlin, C., Busch, D. A. (1987). Primary production. In: Backus, R. H. (ed.) Georges Bank. M.I.T. Press, Boston, p. 220-233

Packard, T. T., Blasco, D., Barber, R. T. (1978). Mesodinium rubrum in the Baja California Upwelling System. In: Boje, R., Tomczak, M. (eds.) Upwelling ecosystems. SpringerVerlag, Berlin, p. 73-89

Parsons, T. R., Maita, Y., Lalli, C. M. (1984a). A manual of chemical and biological methods for seawater analysis. Pergamon Press, New York

Parsons, T. R., Takahashi, M., Hargrave, B. (1984b). Biological oceanographic processes. 3rd edn. Pergamon Press, New York

Pomeroy, L. R. (1974). The ocean's food web, a changing paradigm. Bioscience 24: 499-504

Porter, K. G., Pace, M. L., Battey, J. F. (1979). Ciliate protozoans as links in freshwater planktonic food chains. Nature, Lond. 277: 563-565

Reid, P. C. (1987). Mass encystment of a planktonic oligotrich ciliate. Mar. Biol. 95: 221-230

Rivkin, R. B., Seliger, H. H. (1981). Liquid scintillation counting for ${ }^{14} \mathrm{C}$ uptake of single algal cells isolated from natural populations. Limnol. Oceanogr, 26: 780-781
Sherr, E. B., Sherr, B. F., Fallon, R. D., Newell, S. Y. (1986). Small, aloricate ciliates as a major component of the marine heterotrophic nanoplankton. Limnol. Oceanogr. 31: $177-183$

Sherr, E. B., Sherr, B. F., Paffenhöfer, G.-A. (1986). Phagotrophic protozoa as food for metazoans: a 'missing' trophic link in marine pelagic food webs? Mar. microbial Food Webs 1: $61-80$

Small, E. B., Lynn, D. H. (1985). Phylum Ciliophora. In: Lee, J. J., Hutner, S. H., Bovee, E. C. (eds.) Illustrated guide to the Protozoa. Soc. Protozool. Special Publ., Allen Press, Lawrence, Kansas, p. 393-575

Smith, W. O., Jr, Barber, R. T. (1979). A carbon budget for the autotrophic ciliate Mesodinium rubrum. J. Phycol. 15: 27-33

Sieburth, J. McN., Estep, K. W. (1985). Precise and meaningful terminology in marine microbial ecology. Mar. microbial Food Webs 1: 1-16

Sokal, R. R., Rohlf, F. J. (1981). Biometry, 2nd edn. W. H. Freeman and Co., San Francisco

Stoecker, D. K., Egloff, D. A. (1987). Predation by Acartia tonsa Dana on planktonic ciliates and rotifers. J. exp. mar. Biol. Ecol. 110: 53-68

Stoecker, D. K., Evans, G. T. (1985). Effects of protozoan herbivory and carnivory in a microplankton food web. Mar. Ecol. Prog. Ser, 25: 159-167

Stoecker, D. K., Michaels, A. E., Davis, L. H. (1987a). Large proportion of marine planktonic ciliates found to contain functional chloroplasts. Nature, Lond. 326: 790-792

Stoecker, D. K., Michaels, A. E., Davis, L. H. (1987b). Grazing by the jellyfish, Aurelia aurita, on microzooplankton. J. Plankton Res. 9: 901-915

Stoecker, D. K., Silver, M. W. (1987). Chloroplast retention by marine planktonic ciliates. Endocytobiology III. Ann. N.Y. Acad. Sci. 503: 562-565

Stoecker, D. K., Verity, P. G., Michaels, A. E., Davis, L. H. $(1987 \mathrm{c})$. Feeding by larval and post-larval ctenophores on microzooplankton. J. Plankton Res. 9: 667-683

Stoecker, D. K., Silver, M. W., Michaels, A. E., Davis, L. H. (1988). Obligate mixotrophy in Laboea strobila, a ciliate which retains chloroplasts. Mar. Biol. 99: 415-423

Walsh, J. J. (1981). Shelf-Sea Ecosystems. In: Longhurst, A. R. (ed.) Analyses of marine ecosystems. Academic Press, New York, p. 159-196 